\title{
COMPARATIVE STUDY AGAINST OXIDATIVE STRESS AND DNA DAMAGE PROTECTION ACTIVITY OF THE DIFFERENT EXTRACTS OF TUBERS OF ARISAEMA TORTUOSUM (WALL.) SCHOTT.
}

\author{
PRIYANKA CHAKRABORTY ${ }^{1 *}$, NRIPENDRA NATH BALA ${ }^{1}$, SUDIPTA DAS ${ }^{2}$
}

${ }^{1}$ Department of Pharmacology, BCDA College of Pharmacy and Technology, Barasat, Kolkata, West Bengal, India. ${ }^{2}$ Department of Pharmaceutics, Netaji Subhas Chandra Bose Institute of Pharmacy, Chakdaha, Nadia, West Bengal, India. Email: priyanka290986@gmail.com

Received: 05 November 2019, Revised and Accepted: 25 November 2019

ABSTRACT

Objective: Our main aim is to evaluate the comparative in vitro antioxidant and DNA damage protection activity study with different extracts of tubers of Arisaema tortuosum.

Methods: A. tortuosum (Wall.) Schott. (Araceae family) is commonly known as whipcord cobra lily, used in India as traditional medicine. In vitro, antioxidant activity was done by six methods including determination of total phenolic and total flavonoid compounds. The DNA damage was estimated by standard diphenylamine reaction.

Results: Methanolic extract of tubers of A. tortuosum has been found rich in phenolic and flavonoid compounds when compared with other extracts. Methanolic extract of rhizomes of $A$. tortuosum showed potent antioxidant activity at a concentration of $400 \mu \mathrm{g} / \mathrm{mL}$ and potent the DNA damage protecting activity at a concentration of $50 \mu \mathrm{g} / \mathrm{mL}$.

Conclusion: Comparative study against oxidative damage and protection to the DNA damage protection activity of the different extracts of tubers of A. tortuosum (Wall.) Schott. showed that methanolic extract is most potent, though ethyl acetate extract also showed activity.

Keywords: Antioxidant, DNA damage, Flavonoids, Phenolic compounds.

(C) 2020 The Authors. Published by Innovare Academic Sciences Pvt Ltd. This is an open access article under the CC BY license (http://creativecommons. org/licenses/by/4. 0/) DOI: http://dx.doi.org/10.22159/ajpcr.2020.v13i1.36284

\section{INTRODUCTION}

Oxidative stress is the imbalance into the free radicals production and the body's ability to use the antioxidants to counteract the harmful effects [1]. Interaction between the free radicals which is produced due to oxidation with the molecules within our cells results in damage to nearby cells, mitochondria, and DNA.

Antioxidants in food play a key role in combat with oxidative stress. Antioxidant compounds such as polyphenols, phenolics, and flavonoids are very often found in plants that are reported to have different pharmacological effects as well as antioxidant activity [2].

In recent years, focus on plant research has increased all over the world. Shreds of evidence showed the extremely large promising of traditional medicinal plants for their pharmacological activities and antioxidant principles [3].

Arisaema tortuosum (Wall.) Schott. also known as whipcord cobra lily, the names come from its cobra-like appearance, with a whiplike tongue, up to 12 " long rising vertically. It is a perennial herb also known as Bagh Jandhra in Hindi is an edible vegetable mainly found in the alpine meadows in the Himalaya. This is an ethnomedicinal plant; rhizomes are used for rheumatisms, wound healing, as an antidote, and in many diseases [4].

Although the plant is extensively used by local healers in different states of India and various medicinal values have been described by folklore, to date, no scientific documentation has been demonstrated for the antioxidant potential of this plant. This is the first report dealing with the oxidative DNA damage preventive activity of methanolic extracts of rhizomes of Arisaema tortuosum (Wall.) Schott.

\section{METHODS}

\section{Plant materials}

Fresh rhizomes of A. tortuosum (Wall.) Schott. were collected from Darjeeling district, West Bengal. The botanical identification of the plant was carried out at the Botanical Survey of India, Shibpur, India, and the voucher specimen (BCDAPT/Priyanka/2015-16/01) has been preserved in Pharmacology Research Laboratory, BCDA College of Pharmacy and Technology for future references.

\section{Preparation of plant extracts}

Shade-dried rhizomes of $A$. tortuosum were finely powdered with a blender. About $500 \mathrm{~g}$ of dry powder of rhizomes were extracted with petroleum ether, chloroform, ethyl acetate, and methanol, respectively. The crude extract was processed by maceration for $7 \mathrm{~d}$ and then dried with the use of a rotary vacuum evaporator. The extracts were labeled as petroleum ether extract of $A$. tortuosum (PEAT), chloroform extract of $A$. tortuosum (CHAT), ethyl acetate extract of $A$. tortuosum (EEAT), and methanolic extract of $A$. tortuosum (MEAT).

\section{Chemicals}

All the chemicals were of analytical grade and obtained from HiMedia, Merck, or Fisher, while standard antioxidants were procured from Sigma Aldrich.

Determination of total phenolic compounds

Folin-Ciocalteu colorimetric method for determination of total phenolics present in plant extracts based on oxidation-reduction reaction. Various concentrations of Gallic acid solutions in methanol $(10,25,50,100,200$, and $400 \mu \mathrm{g} / \mathrm{mL})$ were prepared. The reaction mixture was prepared by mixing $1 \mathrm{~mL}$ Gallic acid, $5 \mathrm{~mL}$ of $10 \%$ FolinCiocalteu reagent, and $4 \mathrm{~mL}$ of $7 \% \mathrm{Na}_{2} \mathrm{CO}_{3}$. The blue-colored mixture was incubated for $30 \mathrm{~min}$ at $40^{\circ} \mathrm{C}$ in a water bath. Before that, it was 
shaken well. Then, at $760 \mathrm{~nm}$, the absorbance was measured against blank. The calibration curve was plotted using the average absorbance values obtained at each concentration of Gallic acid [5].

\section{Determination of total flavonoids}

Using the spectrophotometric method, the flavonoid content in the plant extracts was fixed. The reaction mixture was prepared by mixing $1 \mathrm{~mL}$ of the extract in the concentration of $1 \mathrm{mg} / \mathrm{mL}$ with $1 \mathrm{~mL}$ of $2 \% \mathrm{AlCl}_{3}$ solution dissolved in methanol. The incubation of samples was done at room temperature. Then, at $415 \mathrm{~nm}$, absorbance was measured. For the standard rutin solution, the process was the same for defining the calibration curve. The flavonoids concentration $(\mathrm{mg} / \mathrm{mL})$ on the calibration curve was determined based on measured absorbance. The flavonoid content in extracts was disclosed as mg of $\mathrm{RU} / \mathrm{g}$ of the extract $[6,7]$.

\section{ABTS radical scavenging assay}

ABTS radical assay was performed to determine the scavenging activity of plant extracts. For the production of $\mathrm{ABTS}^{+}$radical, a reaction between $7 \mathrm{mM}$ ABTS in water and $2.4 \mathrm{mM}$ potassium persulfate in equal volumes was needed. The reaction mixture was stored in the dark for 12-16 h at room temperature. Ethanol was used for dilution of $\mathrm{ABTS}^{+}$solution which was to give an absorbance of 0.700 at $734 \mathrm{~nm}$. About $2 \mathrm{~mL}$ of the reaction mixture was allowed to react with $200 \mu \mathrm{L}$ of the plant extracts with different concentrations, the reaction mixture was homogenized and after $30 \mathrm{~min}$, and absorbance was measured at $734 \mathrm{~nm}$. The same was done for the ascorbic acid standard of various concentrations. Inhibition percentage calculated using the following formula:

ABTS scavenging effect $(\%)=([\mathrm{AB}-\mathrm{AA}] / \mathrm{AB}) \times 100$;

Where $\mathrm{AB}$ is absorbance of control; $\mathrm{AA}$ is absorbance of sample extract/ standard [8].

1,1-Diphenyl-2-picrylhydrazine (DPPH) radical scavenging activity The antioxidant activity of the plant extract was estimated using the scavenging effect on the DPPH free radical method. The methanolic solution of DPPH $0.05 \mathrm{mM}(300 \mathrm{~mL})$ was mixed with $40 \mathrm{~mL}$ of the extract of different concentrations $(50-400 \mu \mathrm{g} / \mathrm{mL})$. After $5 \mathrm{~min}$, the absorbance of the mixture was measured spectrophotometrically at $517 \mathrm{~nm}$. The radical scavenging activity of the plant extract expressed as percent inhibition was calculated according to the following equation:

DPPH radical scavenging activity $(\%)=\left(\left[\mathrm{Abs}_{\text {control }}-\mathrm{Abs}_{\text {sample }}\right] /\left[\mathrm{Abs}_{\text {control }}\right]\right) \times 100$

Where $\mathrm{Abs}_{\text {control }}$ is the absorbance of DPPH control; $\mathrm{Abs}_{\text {sample }}$ is the absorbance of sample extract/standard [9].

\section{Hydroxyl radical scavenging activity}

Hydroxyl radical scavenging activity of $A$. tortuosum was measured hydroxyl radical generated by Fenton's reaction. The reaction mixture contained deoxyribose $\left(2.8 \mathrm{mM}\right.$ in $\mathrm{KH}_{2} \mathrm{PO}_{4}-\mathrm{KOH}$ buffer, $\mathrm{pH}$ 7.4), $\mathrm{FeCl}_{3}(0.1 \mathrm{mM})$, ethylenediaminetetraacetic acid $(0.1 \mathrm{mM}), \mathrm{H}_{2} \mathrm{O}_{2}(1 \mathrm{mM})$, ascorbate $(0.1 \mathrm{mM})$, and various concentrations of the sample extracts $(50-400 \mu \mathrm{g} / \mathrm{mL})$ in a final volume of $1.0 \mathrm{~mL}$. The mixture was incubated for $1 \mathrm{~h}$ at $37^{\circ} \mathrm{C}$. One $\mathrm{mL}$ of thiobarbituric acid (1\%) and $1 \mathrm{~mL}$ of trichloroacetic acid (TCA) (2.8\%) were mixed with the above mixture and incubated at $100^{\circ} \mathrm{C}$ for $20 \mathrm{~min}$ and then cooled. The absorbance was measured at $532 \mathrm{~nm}$ of the pink-colored solution [10].

\section{Reducing power assay}

The ferric reducing ability of $A$. tortuosum was assessed using the potassium ferricyanide-ferric chloride method. About $0.2 \mathrm{~mL}$ of the extract was mixed with $2.5 \mathrm{~mL}$ phosphate buffer $(0.2 \mathrm{M}, \mathrm{pH} 6.6)$ and $2.5 \mathrm{~mL}$ of a $1 \%$ potassium ferricyanide $\left[\mathrm{K}_{3} \mathrm{Fe}(\mathrm{CN})_{6}\right]$ and incubated at $50^{\circ} \mathrm{C}$ for $20 \mathrm{~min}$. About $2.5 \mathrm{~mL}(10 \%)$ of TCA was added to the mixture followed by centrifugation for $10 \mathrm{~min}(3000 \mathrm{r} / \mathrm{t})$. Finally, $2.5 \mathrm{~mL}$ of the supernatant solution was mixed with $2.5 \mathrm{~mL}$ of distilled water and $0.5 \mathrm{~mL}$ of $\mathrm{FeCl}_{3}(0.1 \%)$ and the absorbance was recorded at $700 \mathrm{~nm}$.
Increased absorbance of the reaction mixture indicated increased reducing power [11].

Inhibition of hydrogen peroxide-induced DNA damage in macrophages cells

Peritoneal macrophages were isolated from the mouse. Those were pre-incubated for $1 \mathrm{~h}$ with different concentrations $(10-50 \mu \mathrm{g} / \mathrm{mL})$ of different extracts. The mixture was further incubated for $2 \mathrm{~h}$ with $\mathrm{H}_{2} \mathrm{O}_{2}(10 \mathrm{mM})$. Further, DNA isolation was done TCA precipitation method. The DNA damage due to oxidative stress was determined by standard diphenylamine reaction $[12,13]$.

\section{Data analysis}

Results were expressed as mean value $\pm S D(n=3)$. Regression analysis was performed to calculate the dose-response relation between the extracts. Linear regression analysis was performed to find out the correlation coefficient. Statistical significance was evaluated employing t-test which was considered to be significant.

\section{RESULTS}

Free radical is a molecule with an unpaired electron and is involved in bacterial and parasitic infections, lung damage, inflammation, reperfusion injury, cardiovascular disorders, atherosclerosis, aging, and neoplastic diseases [14]. They are also involved in an autoimmune disorder such as rheumatoid arthritis [15]. Our results demonstrated that the methanolic extracts of leaf and root of A. tortuosum possess free radical scavenging activity in vitro models such as $\mathrm{DPPH}^{\circ}$; $\mathrm{ABTS}^{\bullet+}$, reducing power activity, and hydroxyl radical scavenging activity.

\section{Total phenolic content (TPC) and total flavonoid content (TFC)}

Among different extracts, methanolic extract (MEAT), the TPC was found from the calibration curve $\mathrm{Y}=0.700 \mathrm{X}-0.869\left[\mathrm{R}^{2}=0.921\right]$ as $120.26 \mathrm{mg} \mathrm{GAE} / \mathrm{g}$ in terms of gallic acid equivalent and the TFC was found from the calibration curve $\mathrm{Y}=0.117 \mathrm{X}-0.077\left[\mathrm{R}^{2}=0.967\right]$, content was found to be $167.27 \mathrm{mg}$ RUE/g in terms of rutin equivalent (Table 1).

\section{ABTS radical scavenging assay}

This study reports that MEAT has the highest antioxidant activity. The scavenging effect of the different plant extracts decreased in the order of methanolic extract $($ MEAT) $>$ ethyl acetate extract $($ EEAT) $>$ chloroform extract (CHAT) $>$ petroleum ether extract (PEAT) (Fig. 1).

\section{DPPH radical scavenging activity}

Among the different extracts tested, interestingly, in the DPPH radical scavenging activity of the $A$. tortuosum methanolic extract exhibited DPPH radical scavenging potential comparable with that of standard ascorbic acid (Fig. 2). The scavenging effect of the different plant extracts decreased in the order of methanolic extract (MEAT) $>$ ethyl acetate extract $($ EEAT) $>$ chloroform extract $(\mathrm{CHAT})>$ petroleum ether extract (PEAT).

\section{Hydroxyl radical scavenging activity}

The scavenging capacity of the MEAT is shown in (Fig. 3). The scavenging effect of the different plant extracts decreased in the order of methanolic extract $(\mathrm{MEAT})>$ ethyl acetate extract $(\mathrm{EEAT})>$ chloroform extract $(\mathrm{CHAT})>$ petroleum ether extract (PEAT).

Table 1: TPC (mg GAE/g) and flavonoid content (mg RUE/g)

\begin{tabular}{lll}
\hline Extract & TPC $(\mathbf{m g ~ G A E} / \mathbf{g})$ & TFC $(\mathbf{m g}$ RUE$/ \mathbf{g})$ \\
\hline Petroleum ether (PEAT) & $08.38 \pm 0.678$ & $12.76 \pm 0.938$ \\
Chloroform (CHAT) & $44.90 \pm 0.809$ & $57.98 \pm 0.628$ \\
Ethyl acetate (EAAT) & $77.87 \pm 0743$ & $93.76 \pm 1.754$ \\
Methanol (MEAT) & $120.26 \pm 0.873$ & $167.27 \pm 0.562$ \\
\hline
\end{tabular}

Results were expressed as mean value \pm SD $(n=3)$. TPC: Total phenolic content, TFC: Total flavonoid content 


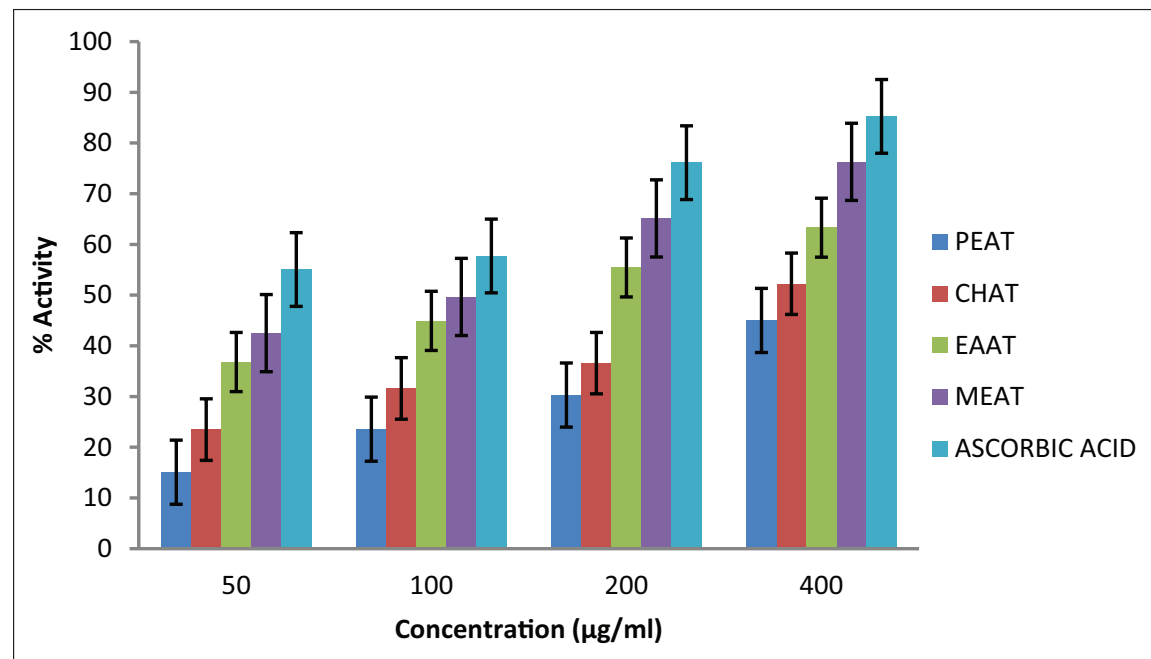

Fig. 1: ABTS radical scavenging assay of the different extracts of Arisaema tortuosum at different concentrations. The data were expressed as mean $\pm S D$. The significance was considered when $p<0.05$

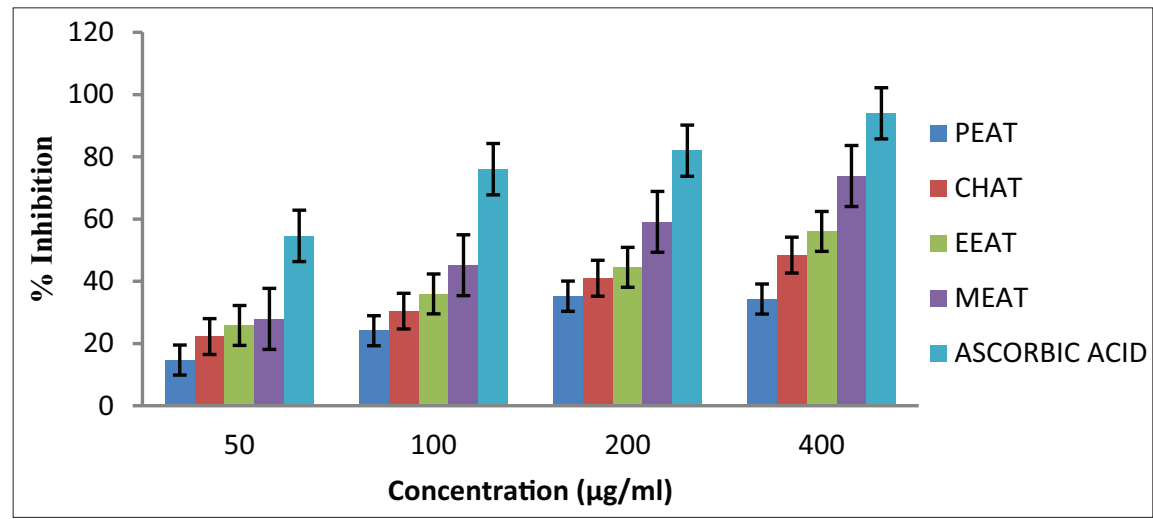

Fig. 2: 1,1-Diphenyl-2-picrylhydrazine radical scavenging activity of the different extracts of Arisaema tortuosum at different concentrations. The data were expressed as mean $\pm \mathrm{SD}$. The significance was considered when $\mathrm{p}<0.05$

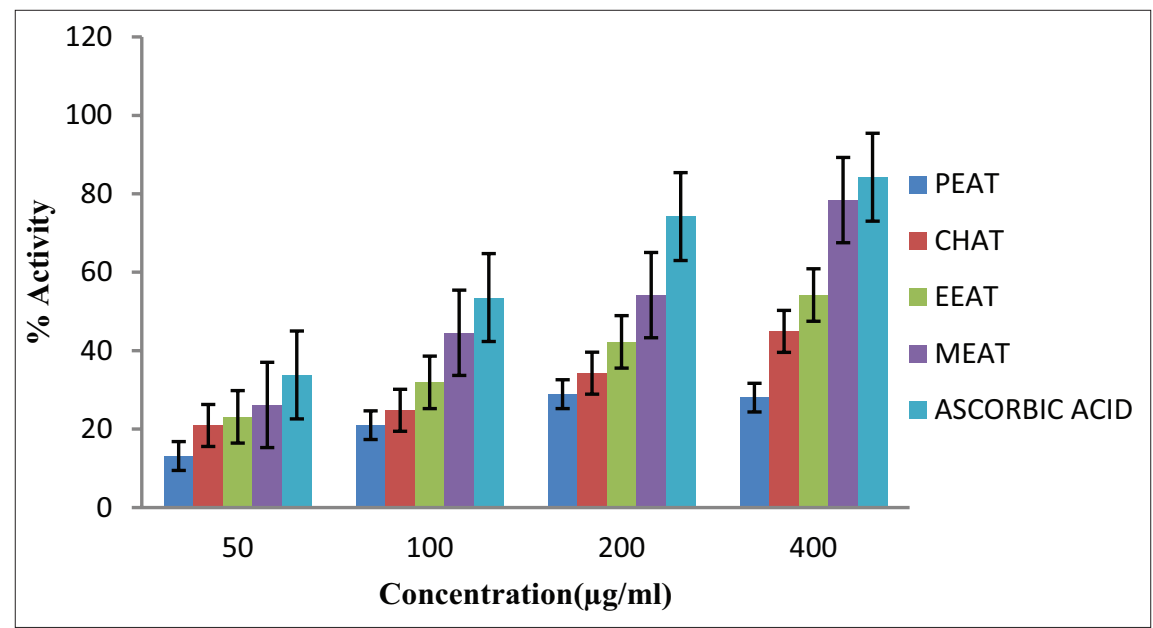

Fig. 3: Hydroxyl radical scavenging activity of the different extracts of Arisaema tortuosum at different concentrations. The data were expressed as mean $\pm \mathrm{SD}$. The significance was considered when $\mathrm{p}<0.05$

\section{Reducing power assay}

Among the different extracts tested, interestingly, in the reducing power assay of the $A$. tortuosum methanolic extract exhibited reducing power potential comparable with that of standard ascorbic acid (Fig. 4). The scavenging effect of the different plant extracts decreased in the order of methanolic extract (MEAT) > ethyl acetate extract (EEAT) > chloroform extract (CHAT) $>$ petroleum ether extract (PEAT).
Inhibition of hydrogen peroxide-induced DNA damage in macrophages cells

$\mathrm{H}_{2} \mathrm{O}_{2}(10 \mathrm{mM})$ significantly $(\mathrm{p}<0.01)$ caused DNA damage in mouse macrophages that were attenuated by MEAT in a concentrationdependent on manner (Table 2). To highlight the mechanism of action, we also checked the in vitro $\mathrm{H}_{2} \mathrm{O}_{2}$ scavenging activity of MEAT. We found that EEAT and MEAT scavenged the $\mathrm{H}_{2} \mathrm{O}_{2}$ in a concentration-dependent 


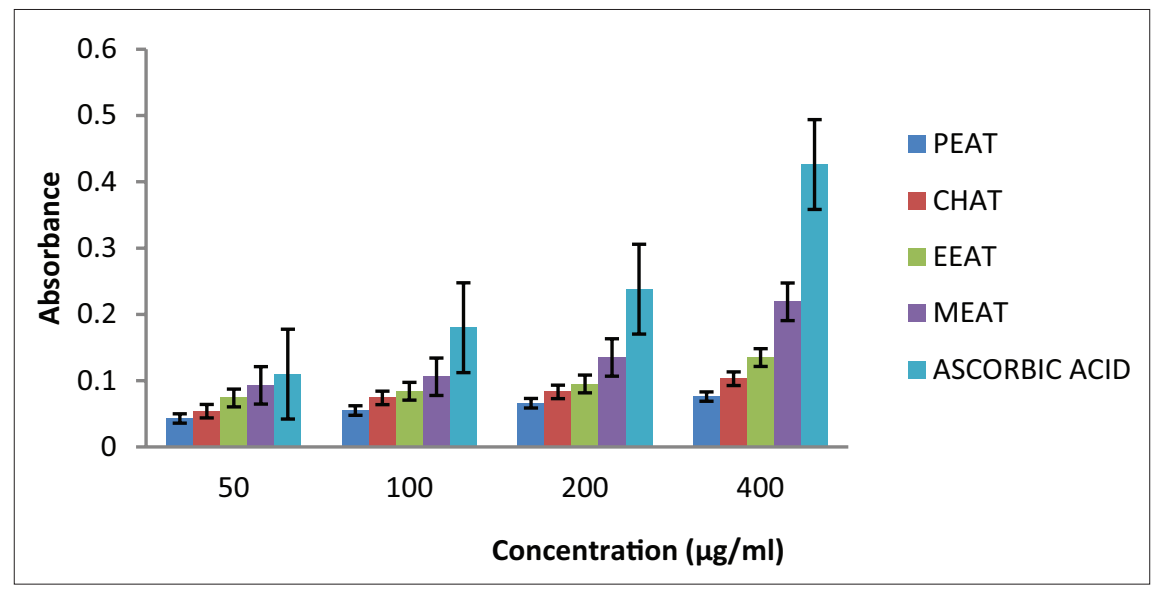

Fig. 4: Reducing power assay of the different extracts of Arisaema tortuosum at different concentrations. The data were expressed as mean $\pm S D$. The significance was considered when $p<0.05$

Table 2: Inhibition of hydrogen peroxide-induced DNA damage in macrophages cells

\begin{tabular}{ll}
\hline Groups (in vitro) & DNA (mM) (mean \pm SEM) \\
\hline Standard (deoxyribose) & $84.23 \pm 0.28$ \\
Negative control & $10.86 \pm 0.78$ \\
PEAT $(10 \mu \mathrm{g} / \mathrm{mL})$ & $12.78 \pm 0.67$ \\
PEAT $(25 \mu \mathrm{g} / \mathrm{mL})$ & $12.89 \pm 0.98$ \\
PEAT $(50 \mu \mathrm{g} / \mathrm{mL})$ & $12.76 \pm 0.56$ \\
CHAT $(10 \mu \mathrm{g} / \mathrm{mL})$ & $12.29 \pm 0.23$ \\
CHAT $(25 \mu \mathrm{g} / \mathrm{mL})$ & $12.23 \pm 0.24$ \\
CHAT $(50 \mu \mathrm{g} / \mathrm{mL})$ & $13.78 \pm 0.73$ \\
EEAT $(10 \mu \mathrm{g} / \mathrm{mL})$ & $20.98 \pm 0.29^{*}$ \\
EEAT $(25 \mu \mathrm{g} / \mathrm{mL})$ & $21.90 \pm 0.66^{*}$ \\
EEAT $(50 \mu \mathrm{g} / \mathrm{mL})$ & $22.45 \pm 0.86^{*}$ \\
MEAT $(10 \mu \mathrm{g} / \mathrm{mL})$ & $27.57 \pm 0.87^{*}$ \\
MEAT $(25 \mu \mathrm{g} / \mathrm{mL})$ & $40.98 \pm 0.64^{* *}$ \\
MEAT $(50 \mu \mathrm{g} / \mathrm{mL})$ & $64.98 \pm 0.84^{* *}$ \\
\hline
\end{tabular}

Results were expressed as mean value \pm SD $(n=3)$. SEM: Standard error of the mean. The significance was considered when $\mathrm{p}<0.05$

manner as discussed above. The scavenging effect of the different plant extracts decreased in the order of methanolic extract (MEAT) $>$ ethyl acetate extract $($ EEAT) $>$ chloroform extract $($ CHAT $)>$ petroleum ether extract (PEAT).

\section{DISCUSSION}

\section{TPC and TFC}

Most of the phenolics and flavonoids are an excellent antioxidant that protects our body from oxidative damage. Synthetic antioxidants such as quinone, BHT, and BHA, are available in market. These phenolics protect our body against oxidative stress [16]; on the other hand, they have some adverse side effects and it leads to the mass campaign to search for natural food, herbs, and species that are rich in antioxidant properties [17]. TPC s are known antioxidants due to redox properties which make them act as reducing agents, hydrogen donors, singlet oxygen quenchers, and as well as potential metal chelators $[18,19]$. Besides, it has been determined that the highest extraction yield was found in methanolic extract.

Flavonoids are a group of polyphenolic compounds, which exhibit several biological effects due to (1) scavenging radical species such as reactive oxygen species (ROS); (2) suppressing R formation of ROS by inhibiting some enzymes involved in free radical production; and (3) protecting antioxidant defense $[20,21]$.

\section{ABTS radical scavenging assay}

The percentage inhibition of absorbance at $734 \mathrm{~nm}$ was measured through the decolorization of the $\mathrm{ABTS}^{*+}$ due to the reduction of the radical cation [22]. Incubating $\mathrm{ABTS}^{*+}$ chromophore generates $\mathrm{ABTS}^{*+}$ through the reaction [23]. The potassium persulfate activity and reduced the production of $\mathrm{ABTS}^{\bullet+}$ was due to the presence of specific chemical compounds in the extracts of $A$. tortuosum may inhibit.

\section{DPPH radical scavenging activity}

DPPH radical scavenging assay is an easy, rapid, and sensitive method for the antioxidant screening of plant extracts. DPPH radical is one of the few stable organic nitrogen free radicals, which has been widely used to determine the free radical scavenging ability of the various samples $[24,25]$. The method is based on the reduction of an alcoholic DPPH solution in the presence of a hydrogen donating antioxidant due to the formation of the non-radical form DPPH-H by the reaction [26]. DPPH radical scavenging activity of the tested extracts is concentrationdependent.

\section{Hydroxyl radical scavenging activity}

The hydroxyl radical is one of the representative ROS generated in the body. These radicals are produced through various biological reactions; one of the common reactions is the Iron (II)-based Fenton reaction. It exhibited the strongest hydroxyl radical scavenging activity. The radical scavenging capacity may be attributed to phenolic compounds in the extract with the ability to accept electrons, which can combine with free radical competitively to decrease hydroxyl radical [27].

\section{Reducing power assay}

Reducing power activity is often used to evaluate the ability of a natural antioxidant to donate electron [28]. Many reports have revealed that there is a direct correlation between antioxidant activities and reducing power of certain plant extracts [29].

Inhibition of hydrogen peroxide-induced DNA damage in macrophages cells

A. tortuosum attenuates the oxidative DNA damage $(\mathrm{p}<0.05)$ to the macrophage cells in a concentration-dependent manner as compared to the respective standards. The highly reactive hydroxyl radical is a major player in oxidative DNA damage that adds to DNA bases or abstracts hydrogen atoms to form various adducts. Hence, $\mathrm{H}_{2} \mathrm{O}_{2}$ is a precursor of this oxidant that insults DNA and hence, quenching of $\mathrm{H}_{2} \mathrm{O}_{2}$ is imperative to protect DNA [30]. To assess the effect of the extracts on oxidative DNA damage induced by $\mathrm{H}_{2} \mathrm{O}_{2}$ in the mouse macrophages cells, we measured its effect on the cells at different concentrations and subsequently, the isolated DNA was estimated by diphenylamine reagent.

\section{CONCLUSION}

The results of the present study indicate that the MEAT exhibits strong antioxidant activities. The scavenging activities observed against ABTS, DPPH, hydroxyl radicals, and as well as the reducing power 
assay; lead us to propose $A$. tortuosum as promising natural sources of antioxidants suitable for application in nutritional/pharmaceutical fields, in the prevention of free radical-mediated diseases. The significant reduction in the levels of, DNA damage, formation by the extract (MEAT) in this study suggests a possible preventive role from oxidative stress which may be due to the minimization of the free radicals or activation of the endogenous antioxidant system or may be due to the presence of reductants in the extract. Subsequently, the $\mathrm{H}^{+}$donating ability of the MEAT implies that it can have a protective role against DNA damage by decreasing the free radical insults to DNA. The results indicated that the MEAT could be a potential natural source of antioxidants and may have greater importance as a natural antioxidant able to slow down or prevent oxidative stress. Further studies are needed to explore the potential phenolics compound(s) from MEAT and in vivo studies are needed for better understanding their mechanism of action.

\section{AUTHORS' CONTRIBUTIONS}

PC made a significant contribution to the acquisition of data, analysis, and drafting of the manuscript. NNB and SD have made a substantial contribution to the design of the experiment.

\section{CONFLICTS OF INTEREST}

The authors declare that they have no conflicts of interest.

\section{REFERENCES}

1. Cheeseman KH, Slater TF. Free radicals in medicine. Br Med Bull 1993;49:479-724.

2. Madamanchi NR, Vendrov A, Runge MS. Oxidative stress and vascular disease. Arterioscler Thromb Vasc Biol 2005;25:29-38.

3. Panchawat S, Rathore KS, Sisodia SS. A review on herbal antioxidants. Int J PharmTech Res 2010;2:232-9.

4. Verma H, Lal VK, Pant KK, Soni N. An ethnomedicinal review on Arisaema tortuosum. Int J Adv Pharm Biol Chem 2012;1:176-9.

5. Alidadi S, Moradi MT, Asadi-Samani M, Lorigooini Z. Antioxidant potential and total phenolic compounds of extracts and fractions of Pistasia atlantica. Int J Pharm Clin Res 2017;9:293-7.

6. Quettier-Deleu C, Gressier B, Vasseur J, Dine T, Brunet C, Luyckx M, et al. Phenolic compounds and antioxidant activities of buckwheat (Fagopyrum esculentum Moench) hulls and flour. J Ethnopharmacol 2000;72:35-42.

7. Jebitta R, Allwin J. Antioxidant activity, total phenolic, flavonoid, and anthocyanin contents of jamun (Syzygium cumini) pulp powder. Asian J Pharm Clin Res 2016;9:361-3.

8. Re R, Pellegrini N, Proteggente A, Pannala A, Yang M, Rice-Evans C. Antioxidant activity applying an improved ABTS radical cation decolorization assay. Free Radic Biol Med 1999;26:1231-7.

9. Brand-Williams W, Cuvelier ME, Berset C. Use of free radical method to evaluate antioxidant activity. Lebens Wiss Technol 1995;28:25-30.

10. Halliwell B, Gutteridge JM, Aruoma OI. The deoxyribose method: A simple "test-tube" assay for determination of rate constants for reactions of hydroxyl radicals. Anal Biochem 1987;165:215-9.
11. Oyaizu M. Studies on product of browning reaction prepared from glucose amine. Jpn J Nutr 1986;44:307-15.

12. Turrens JF. Superoxide production by the mitochondrial respiratory chain. Biosci Rep 1997;17:3-8.

13. Burton K. A study of the conditions and mechanism of the diphenylamine reaction for the colorimetric estimation of deoxyribonucleic acid. Biochem J 1956;62:315-23.

14. McCord JM. The evolution of free radicals and oxidative stress. Am J Med 2000;108:652-9.

15. Scherer R, Godoy HT. Antioxidant activity index (AAI) by the 2 , 2-diphenyl-1-picrylhydrazyl method. Food Chem 2009;112:654-8.

16. Puri SK, Habbu PV, Kulkarni PV, Kulkarni VH. Characterization, in vitro antioxidant and hepatoprotective activity of fungal endophytic extracts of Andrographis paniculata leaves in CCL4 induced hepatotoxicity. Int J Pharm Pharm Sci 2019;11:44-54.

17. Nwakaego NL, Chibuike OK, Chukwugekwu EM, Marylyn AC, Ngozi EI, Chukwunonye ER. In vitro antioxidant and free radical scavenging potential of methanolic extracts of Uvaria chamae leaves and roots. Int J Pharm Pharm Sci 2019;11:67-71.

18. Shahidi F, Wanasundara PK. Phenolic antioxidants. Crit Rev Food Sci Nutr 1992;32:67-103.

19. Hatano T, Edamatsu R, Mori A. Effect of interaction of tannins and related poyphenols on superoxide anion radical and on DPPH radical. Chem Pharm Bull 1989;37:2016-21.

20. Umamaheswari M, Chatterjee TK. In vitro antioxidant activities of the fractions of coccinia grandis L. leaf extract. Afr J Tradit Complement Altern Med 2007;5:61-73.

21. Cao G, Sofic E, Prior RL. Antioxidant and prooxidant behavior of flavonoids: Structure-activity relationships. Free Radic Biol Med 1997;22:749-60.

22. Wu LC, Hsu HW, Chen YC, Chiu CC, Lin YI, Ho JA. Antioxidant and antiproliferative activities of red pitaya. Food Chem 2006;95:319-27.

23. Silva CG, Herdeiro RS, Mathias CJ, Panek AD, Silveira CS, Rodrigues VP, et al. Evaluation of antioxidant activity of Brazilian plants. Pharmacol Res 2005;52:229-33.

24. Pan Y, Wang K, Huang S, Wang H, Mu X, He C, et al. Antioxidant activity of microwave-assisted extract of longan (Dimocarpus longan Lour.) peel. Food Chem 2008;106:1264-70.

25. Panda S, Chakraborty M, Majumder P, Mazumder S, Das S, Haldar PK. Antidiabetic, antioxidant and anti-hyperlipidaemic activity of Cucumis callosus in streptozotocin-induced diabetic rats. Int J Pharm Sci Res 2016;7:1978-84.

26. Lu Y, Foo LY. Antioxidant activities of polyphenols from sage (Salvia officinalis). Food Chem 2001;75:197-202.

27. Klein SM, Cohen G, Cederbaum AI. Production of formaldehyde during metabolism of dimethyl sulfoxide by hydroxyl radical generating systems. Biochemistry 1981;20:6006-12.

28. Chung YC, Chang CT, Chao WW, Lin CF, Chou ST. Antioxidative activity and safety of the 50 ethanolic extract from red bean fermented by Bacillus subtilis IMR-NK1. J Agric Food Chem 2002:50:2454-8.

29. Chanda S, Dave R. In vitro models for antioxidant activity evaluation and some medicinal plants possessing antioxidant properties: An overview. Afr J Microbiol Res 2009;13:981-96.

30. Chakraborty M, Karmakar I, Haldar S, Das A, Bala A, Haldar PK. Amelioration of oxidative DNA damage in mouse peritoneal macrophages by Hippophae salicifolia due to its proton $(\mathrm{H}(+))$ donation capability: Ex vivo and in vivo studies. J Pharm Bioallied Sci 2016;8:210-6. 